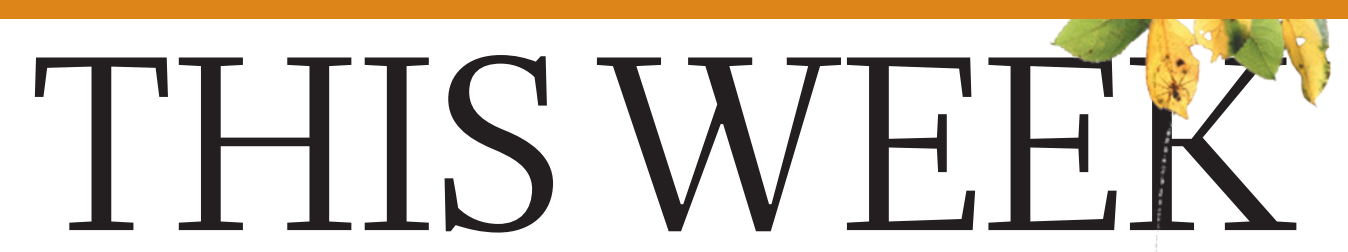

EDITORIALS

ANIMAL RESEARCH Scientists unite to protest against violence p.158
WORLD VIEW China’s citizens must act against air pollution $\mathbf{p} .159$
BEHAVIOUR HOw archerfish find their targets amid distractions p.161

\title{
Right to remain silent
}

\section{The US Supreme Court should overturn the 2003 law that requires federally funded HIV/AIDS programmes abroad to denounce prostitution.}

$\mathrm{W}$ hat kind of strings can government funders attach to the money they hand out to organizations? Controlling how the cash is spent is surely a reasonable one. And the US Supreme Court has ruled in the past that it is fair for the government to prohibit recipients of such funding from saying certain things.

But what about compelling funding recipients to make prescribed statements? Given the importance assigned in the United States to the right to free speech, it might surprise some that the US government has tried to force would-be recipients of funds from a high-profile HIV/AIDS programme to denounce prostitution. It certainly surprised many of the groups involved, who in 2005 brought a lawsuit against the government in protest. In 2006, a district court stopped the restrictions from being enforced while the case wound its way through the courts. Last month, the litigation reached the US Supreme Court. The verdict, expected next month, will be important for any scientist funded by a US agency.

The case, Agency for International Development et al. v. The Alliance for Open Society International, Inc., et al., turns on the wording of the United States Leadership Against HIV/AIDS, Tuberculosis and Malaria Act, a 2003 law that authorized a historic disease-directed government programme. The act allowed Congress to spend US $\$ 44$ billion between 2004 and 2012 to combat HIV/AIDS through the President's Emergency Plan for AIDS Relief (PEPFAR). At the end of 2012, PEPFAR was providing antiretroviral therapy for more than 5.1 million people globally; the same year, it provided HIV testing and counselling for nearly 47 million people, many of them pregnant women.

For all its virtues, the law that established PEPFAR contains the troubling stipulation that none of its funding may go to "any group or organization that does not have a policy explicitly opposing prostitution and sex trafficking". What is more, it states that any group receiving its funds must refrain from speech that the government judges "inconsistent with" that anti-prostitution policy. The prohibition pertains to all activities by the recipient group, even those funded with private money.

At first, even the US Department of Justice deemed the restrictions unconstitutional and declined to enforce them on groups based in the United States. But officials changed their minds in 2005, prompting many non-governmental organizations to sue. One of the litigants InterAction, an alliance based in Washington DC - represents more than 190 US-based groups.

Lawyers for the justice department argue that the government has the authority to ensure that its message is "effectively communicated, and not undermined" by recipients of its funds. In the past, the Supreme Court has agreed - up to a point. For instance, in a landmark abortion case, the high court said that the government did not trample on free speech when it forbade groups receiving US family-planning funds to counsel women to have abortions. But to require a group

to remain silent on a certain issue is quite different from compelling the group, as a condition of funding, to proclaim a point of view it disagrees with - a compulsion that justice Samuel Alito called "a dangerous proposition" during last month's oral arguments.

It is not clear how the high court will rule. If it sides with the government, the immediate result would be sobering. Many private organizations receiving PEPFAR funding would face a choice. They

"The verdict next month will be important for any scientist funded by a US agency."

\section{efforts to educate and deliver health care to sex workers.}

More broadly still, a court decision in favour of the government could open the door to making all manner of grants, including awards to scientists, conditional on the broadcasting of whatever point of view a US funding agency happens to deem desirable at a given time. In the past, the Supreme Court has resisted the compelling of behaviour - as when it refused, for instance, to require students in publicly funded schools to salute the US flag. It should now do so again.

\section{The cleaner state}

Federal regulators could learn much from
California's low-carbon fuel programme.

L ast week, researchers at the University of California, Davis (UC Davis), released their latest analysis of California's Low Carbon Fuel Standard. The 2009 regulation requires oil companies and refineries to reduce the carbon intensity of transportation fuels - how much carbon dioxide they emit per unit of energy - by $10 \%$ by 2020 . For 2013 , this translates to a reduction of $1 \%$, and the UC Davis researchers found that companies racked up enough gains last year to meet half of their obligations for the current year.

The study confirms what California has reported: a steady shift towards cleaner fuels since the regulations took hold in 2011. The idea is that providers can either document their own cuts in carbon intensity or buy credits from others who have gone beyond their requirements. Advanced biofuels - made from waste products or non-food plant material - still make up less than $1 \%$ of the state's fuel, but they represent $10 \%$ of the credits that have gone towards meeting the standard. 
Despite an ongoing legal challenge brought by industry against the regulations, things seem to be working as they should. Daniel Sperling, director of the UC Davis Institute of Transportation Studies and a member of the California Air Resources Board, which implements the standard, calls the progress "modestly positive". That stands in stark contrast to the US federal renewable fuels standard, which is in a state of disarray. The difference between the two is illustrative.

The federal standard sets requirements on the volume of biofuels, including ethanol and biodiesel, that must be blended into the US fuel mix, ramping up from roughly 34 billion litres in 2008 to more than 136 billion litres by 2022. But those requirements do not take into account the realities facing the industry. First, cars and petrol stations are equipped for a fuel blend that is $10 \%$ ethanol, but not all vehicles and few petrol stations can handle more. As a result, the corn-ethanol industry, which supplies the bulk of US biofuels, has hit what is known as the 'blend wall': the $10 \%$ fuel blend means that just 49 billion litres of ethanol are required to saturate the US fuel market, which is below what the law requires from this year forward. This discrepancy is made worse by the fact that demand for fuel has fallen off owing to increased prices and the economic slump; consumption is expected to decline even further as new fuel-economy regulations take hold.

The upshot is general confusion. The US Environmental Protection Agency has approved ethanol blends up to $15 \%$ for use in most vehicles, but few petrol stations are carrying them. Another way around the blend wall is to use E- 85 fuel, which is $85 \%$ ethanol. It can be used by many flexible-fuel vehicles, but further expanding its use will take time. Meanwhile, the agency has been forced to waive the requirements for advanced biofuels. By law, the US fuel mix is required to

contain more than 10 billion litres of advanced biofuels this year, but actual commercial production is barely getting off the ground.

California hit the same blend wall in 2010, but it has still made progress since then. By setting a performance standard, the state has required fuel providers to focus on the carbon content of renewable fuels, not on their volume. This applies regardless of the blend wall, and regardless of what happens to the demand for fuel. Rather than set-

\section{"California} has required fuel providers to focus on the carbon content of renewables." ting thresholds for the production of different kinds of biofuels, this approach drives innovation by recognizing and rewarding incremental progress. The California programme already covers natural gas and electricity, and it might one day be extended to reward advanced technologies such as carbon capture and sequestration within the refining sector.

The upshot is that fuel providers in California have been finding ways around the blend wall and chalking up small gains, largely by shifting to cleaner processes for producing biofuels. The average carbon intensity of petrol and diesel substitutes dropped by $5 \%$ and $6 \%$, respectively, from early 2011 to the end of 2012. Now Sperling and other academics in the National Low Carbon Fuel Standard Project are attempting to put this approach on the national radar. The idea is not entirely new - US President Barack Obama included it in his original energy platform in 2008 - but it has yet to garner political traction in Washington DC. This is unfortunate. As politicians and regulators search for ways to adjust the renewable-fuels mandate in the months and years to come, they would be wise to look west. California might once again be leading the way to smarter environmental policy.

\section{Voice of Pro-Test}

\section{Confidence is rising among scientists defending animal research. It should be encouraged.}

$\mathrm{T}$ The name Pro-Test is becoming a rallying point for scientists standing up to animal-rights extremists. The term was coined by 16-year-old British school pupil Laurie Pycroft in January 2006, when he stumbled across an animal-rights demonstration in Oxford. The activists were protesting against the construction of a university biomedical building with modern animal facilities. Their violent strategies, including the placing of bombs, had already forced some building contractors to pull out. Important research was being hampered, thought Pycroft. He sprang into action, creating the first Pro-Test committee with university students and teachers, and organizing a rally to coincide with the activists' next demonstration the following month.

In what was probably the first mass public showing in defence of animal research, about 1,000 scientists and students attended, overshadowing the 200 -odd animal-rights protestors. That was a tipping point in Britain. Although the country had some of the world's strictest animal-experimentation regulations, its scientists felt at risk from militant antivivisectionists. Most kept their heads below the parapet. But under the Pro-Test banner, they lost their fear of speaking out, particularly after politicians including then-prime minister Tony Blair showed support for their cause. The Oxford facility eventually got built.

Fast forward six years, to Italy. Last July, activists broke into the Green Hill beagle-breeding facility near Brescia, claiming that the animals, many of which were used for mandatory toxicity testing of drugs, were treated cruelly. Police allowed the activists to take the dogs away and a court later said that they could keep custody of the animals, pending investigations. Italy's legal system being notoriously slow, the facility remains shut. Last week, most of the staff were laid off.

Concerned that the police and courts seemed to condone the methods of the animal activists - and that scientists had no safe platform to explain their animal research - a group of Italian scientists created Pro-Test Italia in September. Just in time, as it unhappily turned out: on 20 April, the same activists (by now calling themselves Fermare Green Hill, or Stop Green Hill), broke into an animal facility at the University of Milan, chaining themselves by the necks to the doors and refusing to leave without the animals, mostly mice. Twelve hours later, after tense negotiations, they left with some of the animals - and with police assurance that they could come back for the rest. Before leaving, the activists mixed up the animals and cage labels to sabotage ongoing experiments.

The next day, scores of scientists and students demonstrated in the streets under the Pro-Test Italia banner. A major pro-research demonstration is planned in Milan's city centre on 1 June. The university has refused to let the activists come back, and is preparing to bring charges. Scientists there - from students to the rector - have signed open letters condemning the animal-rights activists' actions and explaining why medical research using animals is important.

The Basel Declaration Society, created in 2010 to encourage scientists to talk openly about their work using animals, has rallied heartening international support for the Milanese scientists. By 7 May, more than 4,000 researchers around the globe had signed its call for solidarity, posted just one week earlier. The call also demands fairer media coverage of research using animals, and zero tolerance from police and policy-makers towards acts of animal-rights extremism.

The use of animal experiments to further medical advances is a delicate issue, and there is no place in the debate for violence. There is, however, a need for scientists to talk openly, and it is encouraging to see their new confidence. Pro-Test Italia is actually the third franchise using Pycroft's term. Pro-Test for Science was set up at the University of California, Los Angeles, four years ago after attacks on researchers. Meanwhile, UK Pro-Test ended operations in 2011, content that it had $\rightarrow$ NATURE.COM To comment online, click on Editorials at: go.nature.com/xhunqv achieved its aim of giving a voice to researchers. It had shown that when it comes to resolving ethical tensions between animal research and medical and veterinary health, we need more scientists prepared to Pro-Test against activist violence. 